\title{
The AMPA receptor as a therapeutic target in epilepsy: preclinical and clinical evidence
}

REVIEW

This article was published in the following Dove Press journal:

Journal of Receptor, Ligand and Channel Research

18 September 2014

Number of times this article has been viewed

\section{Takahisa Hanada ${ }^{1,2}$}

'Neuroscience and General Medicine Product Creation Unit, Eisai Co., Ltd., Tsukuba, Japan; ${ }^{2}$ Center for Tsukuba Advanced Research Alliance, Graduate School of Life and Environmental Sciences, University of Tsukuba, Tsukuba, Japan
Correspondence: Takahisa Hanada Neuroscience and General Medicine Product Creation Unit, Eisai Co., Ltd., Koishikawa 4-6-10, Bunkyo-ku,

Tokyo I 12-8088, Japan

Tel $+8|338| 75235$

Fax $+8 \mid 338 I I 7339$

Email t-hanada@hhc.eisai.co.jp
Abstract: Epilepsy affects around $0.5 \%-1 \%$ of the general population. The most established hypothesis for its underlying pathophysiology is the imbalance of excitatory and inhibitory neuronal activity. The $\alpha$-amino-3-hydroxy-5-methyl-4-isoxazolepropionic acid (AMPA) glutamate receptor has significant roles in fast excitatory neuronal transmission in the central nervous system (CNS) and the plasticity of synaptic strength. Based on this, AMPA-receptor modulation could be a way of adjusting the excitatory-inhibitory balance. The role of the AMPA receptor in epilepsy and epileptogenesis, and its potential as a target for antiepileptic drugs, has been supported by studies in a range of animal models, as well as clinical investigation in humans. However, it has been difficult to develop drugs that target AMPA-receptor activity, especially without considerable CNS-related side effects. In the case of AMPA-receptor antagonists, CNS-depressant side effects had to be overcome before they could be considered viable drugs. Recently, the first selective AMPA receptor antagonist on the market, perampanel, was approved as an adjunctive therapy for the treatment of partial-onset seizures with or without secondarily generalized seizures in patients with epilepsy aged 12 years and older. Further research into the role of AMPA receptors, particularly in the process of epileptogenesis, and the development of AMPA-targeted drugs is warranted.

Keywords: anticonvulsant, antiepileptic, drug discovery research, epileptogenesis, glutamate, perampanel, seizure, synaptic plasticity

\section{Introduction}

Epilepsy is a common neurologic disorder that manifests as recurrent seizures, and affects approximately $0.5 \%-1 \%$ of the general population. ${ }^{1,2}$ While many second- and third-generation antiepileptic drugs (AEDs) have been introduced into clinical practice over the past 20 years, there remains a significant unmet medical need to control seizures, as evidenced by the $15 \%-35 \%$ of all patients with epilepsy who fail to achieve long-term remission. ${ }^{3}$ In order to best address this unmet need, AED research must keep abreast of advances in technology and basic science. To this end, the technical and methodological issues of AED development have been discussed recently as part of several working groups. ${ }^{46}$

The development of AEDs with modes of action (MOAs) based on a pathophysiologic understanding of the condition may represent a rational strategy. With this in mind, the underlying pathophysiologic condition in seizure disorders is believed to be the imbalance of excitatory and inhibitory neuronal activity. ${ }^{7,8}$ Glutamate and gamma-aminobutyric acid (GABA) are the major neurotransmitters that contribute to excitatory and inhibitory activities in the central nervous system (CNS), and both 
have been implicated in seizure development. For example, intoxication with ionotropic glutamate-receptor agonists elicits seizures and neuronal degeneration in animals and humans, ${ }^{9-12}$ while GABA-receptor antagonists (eg, pentylenetetrazole or picrotoxin) also elicit seizures in experimental animals, and are used in animal models of epilepsy. ${ }^{13}$

Many AEDs influence the excitatory-inhibitory balance by modulating excitatory activity, particularly through inhibition of voltage-gated ion channels or enhancement of GABAergic inhibitory activity. ${ }^{14}$ In fact, most AEDs can be divided into five categories (Table 1): 1) ion channel modulators, which can reduce whole-neuron excitability (eg, carbamazepine, lamotrigine) ${ }^{14} ; 2$ ) enhancers of GABAergic transmission,

Table I Classification of antiepileptic drugs

\begin{tabular}{|c|c|c|}
\hline Category & Target molecule & $\begin{array}{l}\text { Antiepileptic } \\
\text { drugs }\end{array}$ \\
\hline \multirow[t]{3}{*}{$\begin{array}{l}\text { lon-channel } \\
\text { modulators (reduce } \\
\text { neuronal excitability) }\end{array}$} & Calcium ion channel & $\begin{array}{l}\text { Ethosuximide } \\
\text { Gabapentin } \\
\text { Pregabalin }^{\mathrm{a}}\end{array}$ \\
\hline & Potassium ion channel & $\begin{array}{l}\text { Retigabine } \\
\text { (ezogabine) }^{\mathrm{a}}\end{array}$ \\
\hline & Sodium ion channel & $\begin{array}{l}\text { Carbamazepine } \\
\text { Eslicarbazepine }^{\mathrm{a}} \\
\text { Lacosamide }^{\mathrm{a}} \\
\text { Lamotrigine }^{\mathrm{a}} \\
\text { Oxcarbazepine }^{\mathrm{a}} \\
\text { Phenytoin } \\
\text { Rufinamide }^{\mathrm{a}}\end{array}$ \\
\hline \multirow{2}{*}{$\begin{array}{l}\text { Enhancers of } \\
\text { GABAergic } \\
\text { transmission } \\
\text { (enhance inhibitory } \\
\text { neurotransmission) }\end{array}$} & $\mathrm{GABA}_{\mathrm{A}}$ & $\begin{array}{l}\text { Clobazam } \\
\text { Clonazepam } \\
\text { Diazepam } \\
\text { Phenobarbital }\end{array}$ \\
\hline & $\begin{array}{l}\text { GABA transporter } \\
\text { GABA transaminase }\end{array}$ & $\begin{array}{l}\text { Tiagabine }^{\mathrm{a}} \\
\text { Vigabatrin }^{\mathrm{a}}\end{array}$ \\
\hline $\begin{array}{l}\text { Modulators of } \\
\text { presynaptic machinery }\end{array}$ & SV2A & $\overline{\text { Levetiracetam }^{\mathrm{a}}}$ \\
\hline $\begin{array}{l}\text { Selective postsynaptic } \\
\text { inhibitors of excitatory } \\
\text { neurotransmission } \\
\text { (reduce excitatory } \\
\text { neurotransmission) } \\
\end{array}$ & AMPA receptor & Perampanel $^{2}$ \\
\hline \multirow[t]{3}{*}{$\begin{array}{l}\text { Multiple modes of } \\
\text { action }\end{array}$} & $\begin{array}{l}\text { Sodium ion channel, } \\
\text { GABA }_{A} \text { receptors, } \\
\text { NMDA receptors }\end{array}$ & Felbamate $^{a}$ \\
\hline & $\begin{array}{l}\text { Sodium ion channel, } \\
\text { AMPA/kainate receptors, } \\
\text { GABA }_{A} \text { receptors }\end{array}$ & Topiramate $^{\mathrm{a}}$ \\
\hline & $\begin{array}{l}\text { Sodium ion channel, } \\
\text { GABA turnover, NMDA } \\
\text { receptors }\end{array}$ & Valproate \\
\hline
\end{tabular}

Note: aSecond- and third-generation antiepileptic drugs.

Abbreviations: AMPA, $\alpha$-amino-3-hydroxy-5-methyl-4-isoxazolepropionic acid; GABA, gamma-aminobutyric acid; NMDA, N-methyl-D-aspartate; SV2A, synaptic vesicle glycoprotein $2 A$. which act via positive allosteric modulation of the $\mathrm{GABA}_{\mathrm{A}}$ receptor (eg, benzodiazepines), reuptake inhibition of GABA (eg, tiagabine), or enzyme inhibition of GABA metabolism (eg, vigabatrin); 3) modulators of presynaptic machinery (levetiracetam, which interacts with the presynaptic protein synaptic vesicle glycoprotein $2 \mathrm{~A}$ [SV2A] and is the only AED in this class $)^{15}$; 4) selective postsynaptic inhibitors of excitatory neurotransmission (perampanel, which is a selective inhibitor of postsynaptic $\alpha$-amino-3-hydroxy-5-methyl-4isoxazolepropionic acid [AMPA] glutamate-receptor activity) and is the only AED in this class; and 5) compounds with multiple MOAs (eg, felbamate, topiramate, and valproate).

This review focuses on the current understanding of the function of the AMPA glutamate receptor and its role in seizures and epilepsy. AED-discovery research and its future will also be discussed, with a focus on AMPA-receptor antagonists.

\section{AMPA receptors: function, structure, and control}

Glutamate is a major excitatory neurotransmitter in the CNS, with two large subclasses of receptors: the ionotropic glutamate receptors and the metabotropic glutamate receptors. The ionotropic receptors can be further subdivided into AMPA, kainate, and $N$-methyl-D-aspartic acid (NMDA) receptors. ${ }^{16-18}$ The AMPA receptor is the major excitatory postsynaptic receptor mediating fast synaptic transmission, and is expressed abundantly throughout the CNS, indicating its physiologic importance. ${ }^{18,19}$

The AMPA receptor comprises four subunits, which include at least two of the following subunit types: GluA1, GluA2, GluA3, or GluA4. ${ }^{20}$ Of particular note, the GluA2 subunit is a determinant of calcium ion $\left(\mathrm{Ca}^{2+}\right)$ impermeability of the AMPA receptor, ${ }^{21}$ and the GluA2-containing $\mathrm{Ca}^{2+}$-impermeable receptor is a major receptor species, especially in glutamatergic projection neurons. In general, GluA2-lacking $\mathrm{Ca}^{2+}$-permeable receptors are expressed in GABAergic interneurons. ${ }^{22,23}$ However, subunit composition can vary depending on physiologic and pathologic conditions. $^{23-28}$

GluA subunits have two alternative splice variants called flip and flop, which exhibit different channel properties. The expression levels of each splice variant are altered during development, ${ }^{29,30}$ and change in response to various diseases or conditions. ${ }^{26,31-36}$ In addition, splice variants can change sensitivity to allosteric modulation of AMPA receptors. ${ }^{37,38}$ Most AMPA receptors are also associated with auxiliary subunits, such as transmembrane AMPA-receptor 
regulatory proteins (TARPs), cornichon homolog (CNIH)-2, CNIH-3, cystine-knot AMPA receptor-modulating protein 44 (CKAMP44), synapse differentiation-induced gene 1, suppressor of Lurcher (SOL)-1, SOL-2, and germcell-specific gene 1-like protein (GSG-1L). ${ }^{39,40}$ These auxiliary subunits can affect receptor kinetics and membrane trafficking of receptors, and their presence can change compounds from specific competitive AMPA-receptor antagonists to partial agonists. ${ }^{40,41}$ Overall, receptor stoichiometry, splice variants, and different auxiliary subunits can control the function of AMPA receptors according to the location of the receptor, cell types, and condition of the cells.

In terms of function, the AMPA receptor also has a significant role in the plasticity of synaptic strength. In general, synaptic strength is determined by trafficking of AMPA receptors into the postsynaptic active zone. ${ }^{42}$ Activation of NMDA receptors, and subsequent activity-dependent insertion of the GluA1-containing AMPA receptor, is believed to be an initial step in synaptic potentiation. The resulting insertion of GluA2-containing AMPA receptors into synapses leads to the stabilization of the synapse. ${ }^{42,43}$ As the increased GluA1 expression and presence of $\mathrm{Ca}^{2+}$ permeable receptors has been confirmed under different conditions, ${ }^{27,44-48}$ such changes in AMPA-receptor subunits may promote the progression of diseases, in addition to their role in established diseases.

\section{The implication of AMPA receptors in human epilepsy}

Domoic acid is a marine neurotoxin that causes neuronal toxicity through activation of AMPA and kainate receptors. ${ }^{49,50}$ In humans, domoic acid can produce amnesic shellfish poisoning, with severe intoxication leading to seizures, causing neuronal damage with a sequela of short-term memory loss. ${ }^{49,51}$ In 1995, Cendes et al were the first to report a case of domoic acid intoxication in a patient who developed status epilepticus (SE) and subsequent spontaneous temporal lobe epilepsy. ${ }^{10}$ Such neuronal toxicity caused by domoic acid is very similar to the spontaneous seizures observed in the experimental kainic acid-induced rodent model of SE. ${ }^{10,52}$ Overall, observations with domoic acid support a hypothesis that overactivation of AMPA receptors could have a role in the progression of hippocampal damage in temporal lobe epilepsy and refractoriness to drugs.

Findings of animal studies are consistent with a role for AMPA receptor activation in the development of epilepsy, including a study of the effects of Thorase, an $\mathrm{AAA}^{+}$ATPase, which regulates the internalization of AMPA receptors.
Genetic deletion of Thorase in mice resulted in increased cell-surface expression of AMPA receptors, as well as death from a seizure-like syndrome between postnatal days 19 and 25 in most animals. ${ }^{53}$

In humans, a pathophysiologic role for AMPA receptors in epilepsy has been indicated by a pharmacologic study of slices of lateral amygdala from patients with medically intractable temporal lobe epilepsy. In this study, blockade of AMPA receptors, but not NMDA receptors, inhibited interictal-like electrical activity, suggesting that AMPA receptors may have a role in abnormal electrical activity in the epileptic brain. ${ }^{54}$ Supporting evidence was provided by an autoradiograph study, which showed an increased density of AMPA receptors in brain slices from patients with epilepsy. ${ }^{54,55}$

Studies in the human epileptic brain have also looked at AMPA-receptor subunit expression: Ying et al demonstrated that expression of the GluA1-receptor subunit is elevated in the epileptic hippocampus, and positively correlates with axonal sprouting. ${ }^{56}$ Increased expression of the GluA1 subunit indicated an increase in levels of the homomeric GluA1 receptor, which exhibits high receptor conductance compared with the GluA2-containing $\mathrm{Ca}^{2+}$-impermeable heteromeric receptors. ${ }^{57,58}$ Of note, increased expression of GluA2-lacking $\mathrm{Ca}^{2+}$-permeable receptors is thought to occur before neuronal degeneration. ${ }^{27,59}$ This is similar to the process of synaptic plasticity, during which insertion of the GluA1 homomeric receptor is also observed, ${ }^{27}$ and thus AMPA receptors may have a significant role in the pathophysiology of epilepsy: not only the expression of seizures but also the progression of epilepsy.

\section{Targeting AMPA receptors in animal models of epilepsy Established effects of AMPA-receptor antagonists in animal models}

Currently available AEDs, especially those with multiple MOAs, have largely been discovered through an empirical research approach using animal seizure models to evaluate novel compounds. ${ }^{13}$ Such an approach has been used to discover AEDs with unique MOAs, including gabapentin ${ }^{60}$ and levetiracetam. ${ }^{61}$ Importantly, the use of this approach has improved understanding of how data from animal models translate into clinical efficacy in patients with epilepsy. ${ }^{13}$ Indeed, the translation to clinical efficacy is perhaps better established for animal seizure models than for animal models of any other neurologic condition. 
Of note, animal seizure models have played a significant role in the demonstration of the functional significance of AMPA receptors in seizures. Key animal models used in epilepsy research are maximal electroshock-induced seizure, pentylenetetrazole-induced seizure and the amygdala-kindling model, which are considered to represent clinical tonic-clonic seizures, myoclonic or absence seizures, and complex partialonset seizures, respectively. ${ }^{62}$ These models were used in the anticonvulsant-screening program at the National Institutes of Health in the US to demonstrate the efficacy of both competitive and noncompetitive AMPA-receptor antagonists. ${ }^{13}$

In the amygdala-kindling model, AMPA-receptor antagonists have been found to reduce the severity of seizures. ${ }^{63,64}$ In addition, AMPA-receptor antagonists have been shown to inhibit seizures in chemically induced seizure models, including pentylenetetrazole, picrotoxin, and 3-mercaptopropionate, ${ }^{11}$ as well as in the $6 \mathrm{~Hz}$ psychomotor-seizure model, ${ }^{65}$ which exhibited less sensitivity to ion channel inhibitors for partialonset seizures than other models, but responded to AEDs for generalized seizures. ${ }^{66}$ While usual stimulation intensity in the $6 \mathrm{~Hz}$ psychomotor-seizure model is $32 \mathrm{~mA}$, many AEDs that show efficacy at $32 \mathrm{~mA}$ become less effective at an increased stimulus intensity of $44 \mathrm{~mA},{ }^{66}$ although the efficacy of AMPAreceptor antagonists has been shown to be maintained without significant reductions in sensitivity. ${ }^{67}$

\section{Ongoing research: animal models of absence seizures}

The mutation underlying the epileptic phenotype of spikewave seizures characteristic of absence epilepsy in stargazer mice is a deficiency of the stargazin gene, which encodes a TARP auxiliary protein that regulates AMPA receptor trafficking and the functional properties of AMPA receptors. ${ }^{68}$ Studies have indicated that it is the loss of AMPA receptors in the thalamus that may be associated with the absenceepilepsy phenotype in the stargazer mouse. ${ }^{69,70}$ In inhibitory neurons, this decrease in AMPA-receptor expression causes activation of the excitatory network, resulting in hypersynchronization of thalamocortical-corticothalamic circuitry. Similarly, GluA4 mutation is also reported in the $\mathrm{C} 3 \mathrm{H} / \mathrm{HeJ}$ strain of mouse, which also exhibits the spike-wave discharge of absence seizures. ${ }^{71}$

While these observations may suggest that AMPAreceptor antagonism could have the potential to induce absence seizures, animal models have indicated that this may not be the case. In general, AMPA-receptor antagonists have not been found to be efficacious in genetic animal models of absence seizures (Genetic Absence Epilepsy Rat from
Strasbourg [GAERS], WAG/Rij], ${ }^{67,72,73}$ but importantly they did not aggravate seizures, which has been reported with some AEDs in a rat model of spontaneous petit mal epilepsy. ${ }^{74}$ Overall, these results suggest that although AMPA-receptor antagonists may not ameliorate absence seizures in animal models, they at least do not worsen seizures. This effect is important when considering an AED to treat severe epileptic syndrome, which usually involves multiple seizure types. In addition, the combination of AMPA-receptor antagonists with other AEDs may confer benefits in absence seizures: low doses of an AMPA-receptor antagonist enhanced the antiabsence effects of ethosuximide in the WAG/Rij rat model, highlighting the contribution of AMPA receptors in thalamocortical hypersynchronization. ${ }^{72}$

\section{Ongoing research: animal models of status epilepticus}

$\mathrm{SE}$ is a neurologic emergency, not restricted to patients with epilepsy, in which the brain is in a state of persistent seizure. ${ }^{75}$ Refractory SE is a serious condition: in a study of adults with SE, $22.6 \%$ of cases did not respond to first- or second-line antiepileptic treatments, and these cases were associated with higher mortality rates than nonrefractory SE (39\% versus $11 \%) .{ }^{76}$ Overall, mortality rates of $30 \%-40 \%$ have been reported in patients with refractory SE. ${ }^{76-79}$ However, there is no established therapy for the treatment of refractory SE, although there are drugs currently available and several are being tested in clinical trials. ${ }^{79}$

Kainate-induced seizure is a well-established model of SE and temporal lobe epilepsy. ${ }^{9}$ As AMPA-receptor responses are not desensitized during exposure to kainic acid, ${ }^{80}$ receptor activation is sustained, and so may be expected to initiate and maintain SE. ${ }^{9}$ The acetylcholine agonist pilocarpine is also used for SE induction. ${ }^{81}$ This model demonstrates refractoriness to benzodiazepine soon after the initiation of $\mathrm{SE},{ }^{82}$ which is thought to result from reductions in surface expression of the $\gamma_{2}$ GABA $_{\mathrm{A}}$-receptor subunit. ${ }^{83}$

Currently available drugs for SE are mainly enhancers of the GABAergic inhibitory system, and so a reduced level of GABA-receptor expression during SE could lessen their potency. On the other hand, AMPA receptor-mediated neuronal transmission is preserved after establishment of benzodiazepine resistance in the pilocarpine model, and AMPA-receptor subunit-expression levels change after SE induction. ${ }^{84}$ This may indicate a central role for the AMPA receptor in the maintenance of SE, and possibly in the neurodegeneration that occurs after SE, following the sequence of aberrant neuronal connection leading to epileptogenesis (the development of 
epilepsy). Therefore, AMPA-receptor antagonists may have the potential to terminate seizures during SE. Indeed, both competitive and noncompetitive AMPA-receptor antagonists have been shown to terminate SE and reduce neuronal degeneration in various SE models. ${ }^{84-87}$ Importantly, the therapeutic time windows of AMPA-receptor antagonists are longer than that of benzodiazepine. ${ }^{85-88}$

\section{Ongoing research: animal models of epileptogenesis}

Recently, epilepsy research has focused on gaps in clinical care, including treatments to target more severe seizure syndromes, comorbidities, and epileptogenesis. ${ }^{4}$ In particular, it is anticipated that the future development of antiepileptogenic therapies will not only benefit those patients at risk of epilepsy as a result of traumatic brain injury but may also slow progression in patients with progressive forms of epilepsy. It is well known that some forms of epilepsy are considered to be progressive, and research has suggested that a greater number of seizures experienced before the start of treatment can be predictive of subsequent pharmacoresistance. ${ }^{89}$ However, an antiepileptogenic approach is very difficult to investigate in clinical trials, due to the long-term treatment that is required and the serious comorbidities of typical study populations (eg, traumatic brain injury). ${ }^{4,90,91}$ As a result, it may be necessary simultaneously to explore disease-modifying and antiseizure effects to advance the development of an AED that could have potential as an antiepileptogenic therapy.

Evidence suggests that the AMPA receptor may have a significant role to play in epileptogenesis, and so could be a useful target for the development of AEDs. Membrane targeting of AMPA receptors during the development of synaptic strength ${ }^{25}$ is associated with the development of hyperexcitability of the neuronal circuit, a characteristic feature of epileptogenesis. ${ }^{92}$ Indeed, in the audiogenic kindling model of epileptogenesis, there were increased numbers of AMPAreceptor subunits in the inferior colliculus, although GluA2 expression was reduced. ${ }^{93}$ Similarly, Sommer et al reported transient decreases in GluA2-subunit expression in hippocampal neurons following kainic acid-induced seizures in rats, ${ }^{94}$ and Prince et al reported downregulation of GluA2, and increases in levels of $\mathrm{Ca}^{2+}$-permeable AMPA receptors, in the piriform cortex in an amygdala-kindling model. ${ }^{95}$ Such events may lead to longterm changes in AMPA receptor-mediated currents, and could contribute to the pathogenesis of chronic seizures. Therefore, AMPA-receptor density, subunit composition, and ultimately physiologic characteristics may be changed, and could represent an important factor in the process of epileptogenesis.
The role of the AMPA receptor in epileptogenesis in the developing brain has been studied in detail using cases of neonatal seizures. Of note, neonatal hypoxia in rats increased sensitivity to kindling without activation of NMDA receptors, which suggests an increased contribution of AMPA receptors to epileptogenesis in neonatal hypoxia-induced seizures. ${ }^{96}$ Studies of animals that experienced neonatal hypoxia have shown cognitive sequelae and deficiency of social interaction, such as autism, and also spontaneous seizures in later life. ${ }^{96-98}$

Interestingly, hypoxic neonatal seizures have been associated with increased levels of GluA2-lacking $\mathrm{Ca}^{2+}$-permeable AMPA receptors. Expression of these receptors is high around the perinatal time in humans ${ }^{99}$ and the equivalent 10 postnatal days in rats. ${ }^{100}$ It has been reported that hypoxic seizures in rats at postnatal day 10 reduced levels of GluA2 expression, causing a further increase in the proportion of $\mathrm{Ca}^{2+}$-permeable AMPA receptors. ${ }^{96}$

Neonatal seizures have also been reported to change the phosphorylation state of AMPA receptors. Rakhade et al demonstrated that seizures in immature rats and human neonatal seizures (studied using samples from autopsy cases) led to an increase in phosphorylation of the GluA1 subunit at serine 831 (S831) and S845 sites. ${ }^{101}$ Seizures in immature rats also caused an increase in AMPA receptor-mediated synaptic transmission. Transgenic mice with a deficit at both the S831 and S845 sites had a reduced sensitivity to seizures in later life, suggesting that the enhanced activity of the AMPA receptor underlies later-life hyperexcitability in neuronal networks. ${ }^{101}$

A preventive effect of AMPA-receptor antagonists on later-life seizures and behavioral changes has been evaluated in rats that had experienced neonatal hypoxia. In these animals, pretreatment with the AMPA-receptor antagonists NBQX (2,3-dihydroxy-6-nitro-7-sulfamoyl-benzo[f] quinoxaline-2,3-dione) or talampanel reduced later-life hypersensitivity to seizure-inducing stimuli. ${ }^{102,103} \mathrm{NBQX}$ also prevented the increase in susceptibility to kainic acid seizureinduced hippocampal neuronal injury in later life, even when the treatment was administered 48 hours after hypoxia. In addition, in a separate study in rats, spontaneous seizures and impairment of social interaction were ameliorated by posthypoxic treatment with NBQX. ${ }^{104}$

Research also suggests that agents that indirectly target the AMPA receptor may have antiepileptogenic effects. The activation of the mammalian target of rapamycin (mTOR) is known to have a role in synaptic plasticity, ${ }^{105}$ and Sun et al demonstrated that mTOR may be involved in the negative regulation of homeostatic mechanisms that 
downregulate enhanced AMPA-receptor function following hypoxia-induced neonatal seizures in rodents. ${ }^{92}$ Accordingly, the mTOR inhibitor rapamycin appeared to prevent the impairment of these homeostatic mechanisms. Indeed, rapamycin has been found to confer epileptostatic and antiepileptogenic effects in some animal models. ${ }^{106-108}$

Overall, studies have indicated a role for AMPA receptors in the neuronal plasticity observed in various seizurerelated conditions. In particular, AMPA receptors have been implicated in epileptogenesis following hypoxic neonatal seizures in rodents, although further studies are required to elucidate its potential contribution to epileptogenesis in adult models. An overview of the mechanism of neuronal plasticity in epileptogenesis and potential intervention with AMPA-receptor antagonists is shown in Figure 1.

\section{The clinical development of AMPA-receptor antagonists Obstacles to the clinical development of AMPA-receptor antagonists}

Many AEDs that target glutamate receptors have been investigated in clinical studies. However, as with other drugs, there have been challenges to overcome involving their chemistry and tolerability. One well-recognized case is that of the NMDA-receptor antagonists, which were associated with modest receptor inhibition ${ }^{109,110}$ and evidence of additional MOAs, but posed a challenge due to psychotomimetic side effects in animals and humans. ${ }^{111,112}$ In the case of the AMPA-receptor antagonists, CNS-depressant side effects were an issue, but considered unavoidable given the key role of AMPA receptors in fast excitatory neurotransmission. Accordingly, Yamaguchi et al showed that AMPA-receptor antagonists with different MOAs exhibited antiseizure effects in rodents, but were associated with motor incoordination. ${ }^{113}$ AMPA-receptor antagonists also tended to have a particularly narrow therapeutic index compared with other AEDs, except for valproate. ${ }^{66,104,113}$ This was a major setback for the development of AMPAreceptor antagonists as drugs for a chronic disease, such as epilepsy. As a result, many pharmaceutical companies tried to discover novel AMPA-receptor antagonists for the treatment of acute neurodegenerative disorders, mainly stroke. The clinical trial of the antagonist ZK-200775, however, was terminated prematurely, because a strong sedative effect was confirmed in the acute stroke population. ${ }^{114}$
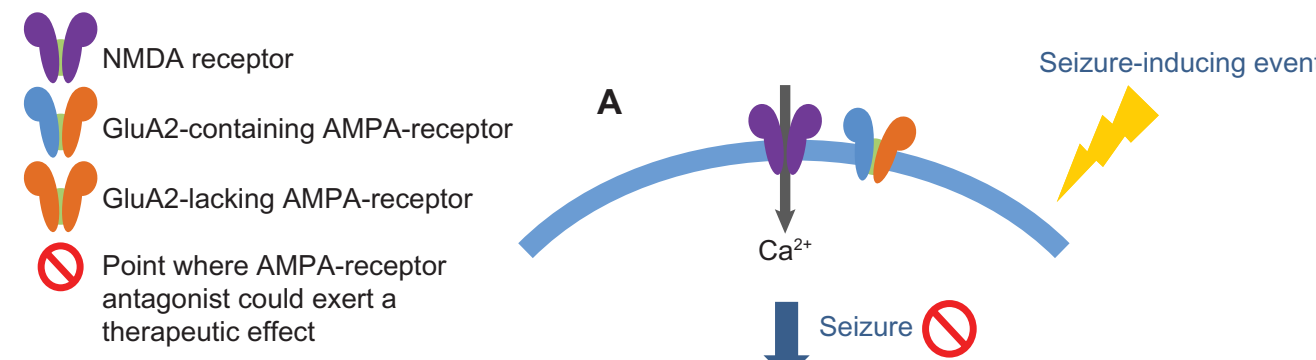
therapeutic effect

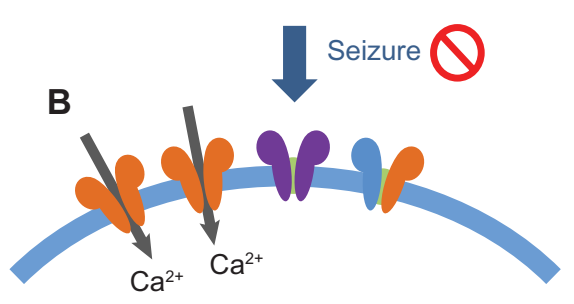

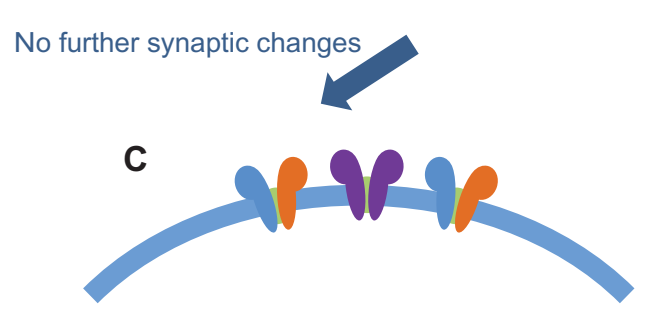

Nonepileptic brain

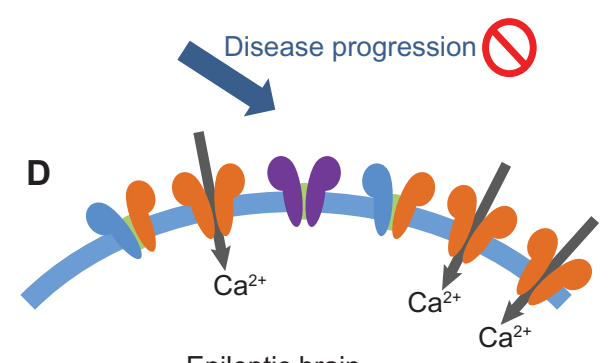

Epileptic brain

Figure I Mechanism of epileptogenesis and potential therapeutic intervention with AMPA-receptor antagonists.

Notes: (A) A seizure-inducing event, such as a brain trauma, triggers a seizure (seizure may be inhibited by an AMPA-receptor antagonist); (B) seizure results in the incorporation of GluA2-lacking AMPA receptors at the synapse, enhancing synaptic strength; $(\mathbf{C})$ in cases where epileptogenesis does not occur, there are no further synaptic changes; (D) alternatively, further incorporation of GluA2-lacking AMPA receptors may occur, leading to epileptogenesis (it is hypothesized that AMPA-receptor antagonists may delay or prevent this process).

Abbreviations: AMPA, $\alpha$-amino-3-hydroxy-5-methyl-4-isoxazolepropionic acid; NMDA, N-methyl-D-aspartate. 
Many pharmaceutical companies conducted drugdiscovery research to identify AMPA-receptor antagonists suitable for clinical development. Some companies investigated orthosteric antagonists of quinoxaline-dione, while others investigated negative allosteric modulators of 2,3-benzodiazepine muscle relaxants. ${ }^{115-117}$ In general, permeability of the blood-brain barrier to the orthosteric antagonists was extremely low, which can result in peripheral side effects. ${ }^{104,118}$ On the other hand, the 2,3benzodiazepine negative allosteric modulators showed weak intrinsic activity but good efficacy in animal models, indicating good permeability of the blood-brain barrier. ${ }^{118}$ The drug-discovery efforts of two different pharmaceutical companies led to the clinical development of two AMPAreceptor antagonists: talampanel and perampanel. A third AMPA-receptor antagonist, selurampanel, has also undergone early preclinical and clinical evaluation, although published clinical data are currently limited. ${ }^{119}$ In a study of acute migraine, selurampanel demonstrated some reduction of pain severity compared with placebo and a similar painfree response rate as sumatriptan, but the proof-of-concept criterion was not met and the incidence of adverse events was relatively high. ${ }^{120}$

\section{Talampanel}

Talampanel is a 2,3-benzodiazepine negative allosteric modulator that was the first AMPA-receptor antagonist to enter clinical trials for chronic indications, including epilepsy, amyotrophic lateral sclerosis, and malignant brain cancer. ${ }^{121-123}$ It has a relatively short half-life in humans, and inhibited AMPA-receptor function at a $10^{-6} \mathrm{M}$ concentration. ${ }^{124}$ In a Phase II trial in patients with refractory epilepsy (ClinicalTrials.gov identifier: NCT00034814), talampanel reduced seizure frequency, with a median seizure reduction of $21 \%$, although clinical studies were suspended. ${ }^{121}$ Another Phase II trial of talampanel (NCT00696332), this time for treatment of amyotrophic lateral sclerosis, showed that it was associated with a trend toward a slower decline of muscle strength and functioning compared with placebo, but the results were not confirmed in a Phase III trial. ${ }^{122}$ Talampanel demonstrated acceptable tolerability in a malignant brain cancer population (NCT00062504), but clinical development was not continued. ${ }^{123}$ The results of an antidyskinetic effect in a study of patients with advanced Parkinson's disease have not yet been published (NCT00036296). Despite clinical trials in various diseases, talampanel did not reach the market, perhaps due to its complex metabolism and short half-life. ${ }^{125}$

\section{Perampanel}

The noncompetitive AMPA-receptor antagonist perampanel has a 1,3,5-triaryl-1 $H$-pyridin-2-one core structure, and was identified from high-throughput screening combined with structure-activity analyses. ${ }^{115}$ In an in vitro assay, perampanel inhibited AMPA-receptor function at a half-maximal inhibitory concentration of $60 \mathrm{nM}$. In early clinical studies, perampanel was shown to have a long half-life in humans (66-90 hours after multiple-dose administration), and its plasma concentration was shown to gradually increase before reaching a steady state, which suggests a relatively smooth pharmacokinetic profile that could be expected to confer good tolerability during dose titration. ${ }^{126,127}$ Clinical trials were designed to enable the development of tolerance. In addition, perampanel was administered before bedtime, which allowed patients to achieve maximal plasma concentration during their sleep to minimize the potential for CNS-depressant effects during the day. ${ }^{128}$

The antiseizure effect of perampanel was confirmed in three Phase III registration trials in patients with uncontrolled partial-onset seizures despite treatment with one to three AEDs (NCT00699972, NCT00699582, NCT00700310). ${ }^{129-131}$ These clinical studies were more rigorous than those of second-generation AEDs. Perampanel showed a significant antiseizure effect at a dose of $4 \mathrm{mg}$, which appeared to be the minimum efficacious daily dose. Efficacy increased at the $8 \mathrm{mg}$ and $12 \mathrm{mg}$ doses, but there appeared to be a ceiling effect between $8 \mathrm{mg}$ and $12 \mathrm{mg}$. This was likely due to the study protocol, which allowed dose reductions during the titration period according to tolerability. Analysis of pharmacokinetics and pharmacodynamics demonstrated that perampanel was associated with a clear exposure-efficacy relationship. ${ }^{132}$ An increase in treatment-emergent adverse events was generally observed at higher doses, with dizziness, somnolence, and headache being the most frequent adverse events. The efficacy and safety of perampanel in these clinical trials and other studies have been reviewed in depth elsewhere. ${ }^{128,133-136}$

Based on the results of these trials, perampanel was approved as an adjunctive therapy for the treatment of partial-onset seizures with or without secondarily generalized seizures in patients with epilepsy aged 12 years and older. ${ }^{126,137}$ It was the first selective inhibitor of postsynaptic excitatory neurotransmission to be approved in Europe, the US, Canada, Switzerland, and more than 30 other countries. Perampanel is a good example of how a drug-discovery approach can utilize a specific molecular target that has previously been associated with challenges, such as subjective CNS effects. 


\section{Considerations for future research}

One question that remains to be answered is the role of the AMPA receptor in disease modification. While intensive research has highlighted the role of the AMPA receptor in neonatal seizures and subsequent later-life changes, the exact role of the AMPA receptor in epileptogenesis and the effects of AMPA-receptor antagonists have not been well studied, and further nonclinical investigations are warranted. In particular, more data are needed on the potential therapeutic time window of AMPA-receptor antagonists.

For the future development of AMPA receptors, the case of perampanel has demonstrated the importance of considering the pharmacokinetic properties of a compound, particularly with regard to the induction of tolerance. In drug-discovery research, the properties of a compound can be associated with favorable or negative effects, which can be refined or overcome. The different MOAs of sodium ion $\left(\mathrm{Na}^{+}\right)$-channel inhibitors provide a useful example: on the one hand, the selective $\mathrm{Na}^{+}$channel blocker tetrodotoxin is a neurotoxin, while on the other hand class IA-IC antiarrhythmic drugs interfere with the $\mathrm{Na}^{+}$channel according to the Vaughan Williams classification and have therapeutic applications. ${ }^{138}$ Blockers of the N-type $\mathrm{Ca}^{2+}$ channel provide a similar example: gabapentinoids, which bind to the $\alpha_{2} \delta$ subunit of $\mathrm{Ca}^{2+}$ channels to modulate channel activity and membrane transport, can be used as oral AEDs or analgesics, ${ }^{139}$ but systemic administration of the selective $\mathrm{Ca}^{2+}$ channel blockers conotoxin MVIIA and its synthetic form, ziconotide, causes neurotoxic adverse events (eg, hypotension, tremor), and, thus intrathecal administration is required. ${ }^{140}$

As the AMPA receptor has different receptor stoichiometry and auxiliary subunits, multiple drug-binding sites might be utilized, which will aid in the design of new AMPA-receptor modulators (Figure 2). Various diseases are associated with different AMPA-receptor subunit-expression patterns and physiologic function, which are reasonably similar to changes observed in neuronal plasticity. Overall, compounds with other MOAs could be beneficial for the treatment of different diseases.

In addition, the consideration of compounds that bind to different sites on AMPA receptors may help to target receptors in specific brain regions, potentially minimizing adverse events, such as CNS-depressant effects. For example, compounds designed to modulate the function of auxiliary subunits could theoretically enable selective targeting of AMPA receptors based on the regional expression of the auxiliary subunits. Alternatively, ion channel blockers can be developed to confer activity at a given ion channel in a useor voltage-dependent manner, and so this mechanism could also be a way to facilitate more specific targeting of AMPA receptors. This could build on experience with memantine, a voltage-dependent NMDA receptor-channel blocker, which

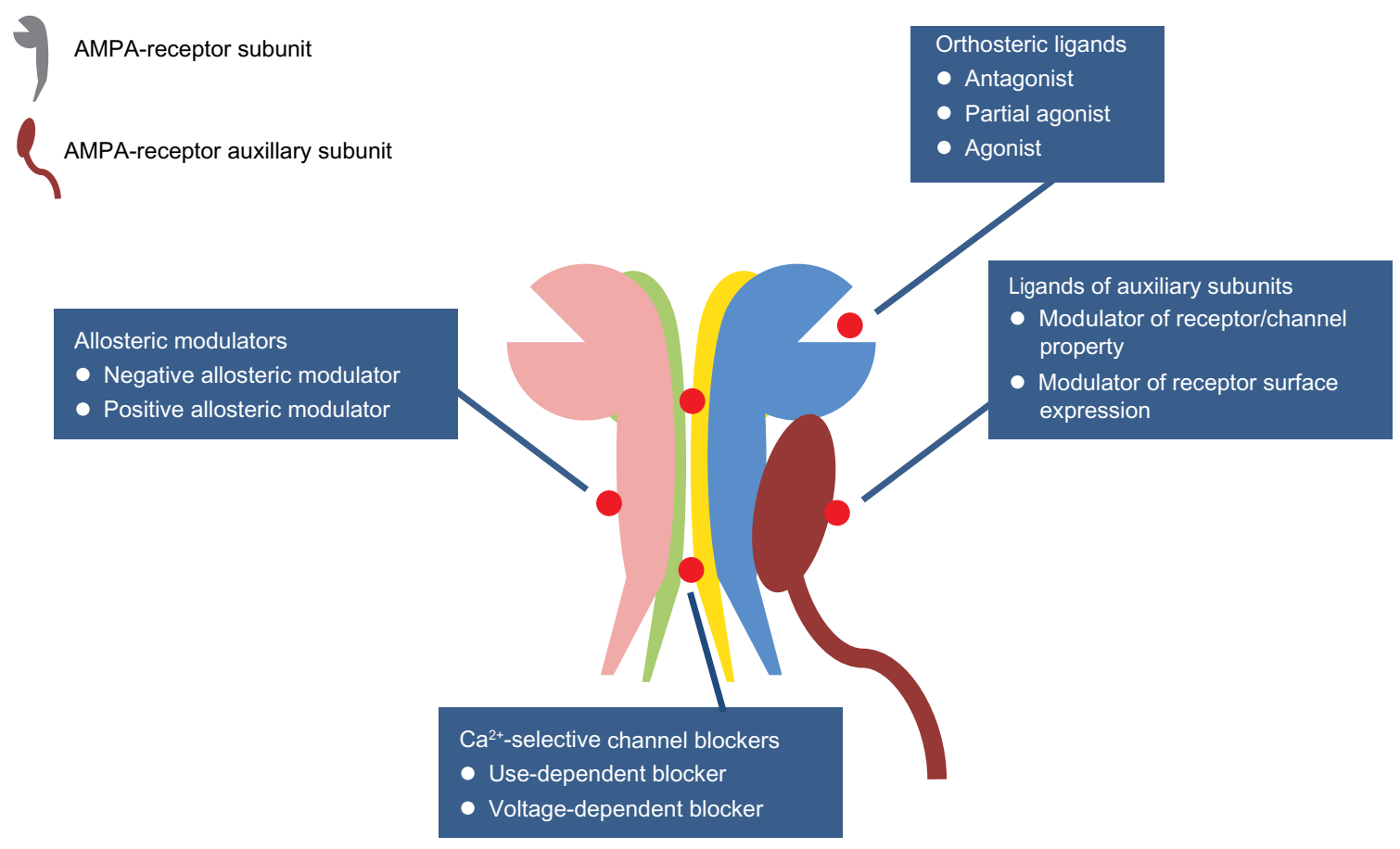

Figure 2 Sites of action of different AMPA receptor-targeted agents.

Abbreviation: AMPA, $\alpha$-amino-3-hydroxy-5-methyl-4-isoxazolepropionic acid. 
unlike other NMDA receptor-channel blockers, does not cause psychotomimetic effects at therapeutic doses. ${ }^{141}$

\section{Conclusion}

The antiseizure effects of AMPA-receptor antagonists observed in animal models have been validated in clinical trials. While early efforts to develop clinically effective AMPA-receptor antagonists were hampered by pharmacologic limitations, these challenges were eventually overcome using classic drug-discovery approaches. This led to the identification of perampanel, a drug inhibiting the excitation of postsynaptic membranes through the selective inhibition of AMPA receptors. Perampanel reduced seizure frequency with an acceptable adverse-event profile in patients with partial-onset seizures. Recent progress in the understanding of epileptogenesis suggests that the AMPA receptor could play a role in the process. Further research is needed to fully understand the development of epilepsy and to inform future treatment strategies to target the AMPA receptor.

\section{Acknowledgments}

This author-written manuscript was edited for English by Hannah FitzGibbon, PhD, Complete Medical Communications, with funding from Eisai Inc.

\section{Disclosure}

Takahisa Hanada is an employee of Eisai. The author has no other conflict of interest in this work.

\section{References}

1. Abu Saleh T, Stephen L. Lennox gastaut syndrome, review of the literature and a case report. Head Face Med. 2008;4:9.

2. Ngugi AK, Bottomley C, Kleinschmidt I, Sander JW, Newton CR. Estimation of the burden of active and life-time epilepsy: a meta-analytic approach. Epilepsia. 2010;51(5):883-890.

3. Shorvon SD, Goodridge DM. Longitudinal cohort studies of the prognosis of epilepsy: contribution of the National General Practice Study of Epilepsy and other studies. Brain. 2013;136(Pt 11):3497-3510.

4. French JA, White HS, Klitgaard H, et al. Development of new treatment approaches for epilepsy: unmet needs and opportunities. Epilepsia. 2013;54 Suppl 4:3-12.

5. Galanopoulou AS, Kokaia M, Loeb JA, et al. Epilepsy therapy development: technical and methodologic issues in studies with animal models. Epilepsia. 2013;54 Suppl 4:13-23.

6. Wilcox KS, Dixon-Salazar T, Sills GJ, et al. Issues related to development of new antiseizure treatments. Epilepsia. 2013;54 Suppl 4: 24-34.

7. Lason W, Chlebicka M, Rejdak K. Research advances in basic mechanisms of seizures and antiepileptic drug action. Pharmacol Rep. 2013;65(4):787-801.

8. McCormick DA, Contreras D. On the cellular and network bases of epileptic seizures. Annu Rev Physiol. 2001;63:815-846.

9. Ben-Ari Y. Limbic seizure and brain damage produced by kainic acid: mechanisms and relevance to human temporal lobe epilepsy. Neuroscience. 1985;14(2):375-403.
10. Cendes F, Andermann F, Carpenter S, Zatorre RJ, Cashman NR. Temporal lobe epilepsy caused by domoic acid intoxication: evidence for glutamate receptor-mediated excitotoxicity in humans. Ann Neurol. 1995;37(1):123-126.

11. Turski L, Jacobsen P, Honoré T, Stephens DN. Relief of experimental spasticity and anxiolytic/anticonvulsant actions of the alpha-amino-3hydroxy-5-methyl-4-isoxazolepropionate antagonist 2,3-dihydroxy6-nitro-7-sulfamoyl-benzo(F)quinoxaline. J Pharmacol Exp Ther. 1992;260(2):742-747.

12. Turski W, Turski L, Czuczwar SJ, Kleinrok Z. (RS)-alpha-amino-3hydroxy-5-methyl-4-isoxazolepropionic acid: wet dog shakes, catalepsy and body temperature changes in rats. Pharmacol Biochem Behav. 1981;15(4):545-549.

13. Smith M, Wilcox KS, White HS. Discovery of antiepileptic drugs Neurotherapeutics. 2007;4(1):12-17.

14. Löscher W, Schmidt D. Epilepsy: Perampanel-new promise for refractory epilepsy? Nat Rev Neurol. 2012;8(12):661-662.

15. Lynch BA, Lambeng N, Nocka K, et al. The synaptic vesicle protein SV2A is the binding site for the antiepileptic drug levetiracetam. Proc Natl Acad Sci U S A. 2004;101(26):9861-9866.

16. Featherstone DE. Intercellular glutamate signaling in the nervous system and beyond. ACS Chem Neurosci. 2010;1(1):4-12.

17. Meldrum BS. Glutamate as a neurotransmitter in the brain: review of physiology and pathology. J Nutr. 2000;130(Suppl 4S):1007S-1015S.

18. Seeburg PH. The TINS/TiPS lecture. The molecular biology of mammalian glutamate receptor channels. Trends Neurosci. 1993;16(9): 359-365.

19. Rogawski MA. Revisiting AMPA receptors as an antiepileptic drug target. Epilepsy Curr. 2011;11(2):56-63.

20. Mansour M, Nagarajan N, Nehring RB, Clements JD, Rosenmund C. Heteromeric AMPA receptors assemble with a preferred subunit stoichiometry and spatial arrangement. Neuron. 2001;32(5):841-853.

21. Hollmann M, Hartley M, Heinemann S. Ca2+ permeability of KA-AMPA-gated glutamate receptor channels depends on subunit composition. Science. 1991;252(5007):851-853.

22. Geiger JR, Melcher T, Koh DS, et al. Relative abundance of subunit mRNAs determines gating and $\mathrm{Ca} 2+$ permeability of AMPA receptors in principal neurons and interneurons in rat CNS. Neuron. 1995;15(1):193-204.

23. He Y, Janssen WG, Vissavajjhala P, Morrison JH. Synaptic distribution of GluR2 in hippocampal GABAergic interneurons and pyramidal cells: a double-label immunogold analysis. Exp Neurol. 1998;150(1):1-13.

24. de Lanerolle NC, Eid T, von Campe G, Kovacs I, Spencer DD, Brines M. Glutamate receptor subunits GluR1 and GluR2/3 distribution shows reorganization in the human epileptogenic hippocampus. Eur $J$ Neurosci. 1998;10(5):1687-1703.

25. Kessels HW, Malinow R. Synaptic AMPA receptor plasticity and behavior. Neuron. 2009;61(3):340-350.

26. Kobylecki C, Crossman AR, Ravenscroft P. Alternative splicing of AMPA receptor subunits in the 6-OHDA-lesioned rat model of Parkinson's disease and L-DOPA-induced dyskinesia. Exp Neurol. 2013;247:476-484.

27. Liu SJ, Zukin RS. Ca2+-permeable AMPA receptors in synaptic plasticity and neuronal death. Trends Neurosci. 2007;30(3):126-134.

28. Liu Y, Formisano L, Savtchouk I, et al. A single fear-inducing stimulus induces a transcription-dependent switch in synaptic AMPAR phenotype. Nat Neurosci. 2010;13(2):223-231.

29. Jakowec MW, Jackson-Lewis V, Chen X, Langston JW, Przedborski S The postnatal development of AMPA receptor subunits in the basal ganglia of the rat. Dev Neurosci. 1998;20(1):19-33.

30. Monyer H, Seeburg PH, Wisden W. Glutamate-operated channels: developmentally early and mature forms arise by alternative splicing. Neuron. 1991;6(5):799-810.

31. Acosta G, Freidman DP, Grant KA, Hemby SE. Alternative splicing of AMPA subunits in prefrontal cortical fields of cynomolgus monkeys following chronic ethanol self-administration. Front Psychiatry. 2012;2:72 
32. Eastwood SL, Burnet PW, Harrison PJ. GluR2 glutamate receptor subunit flip and flop isoforms are decreased in the hippocampal formation in schizophrenia: a reverse transcriptase-polymerase chain reaction (RT-PCR) study. Brain Res Mol Brain Res. 1997;44(1):92-98.

33. Gitaí DL, Martinelli HN, Valente V, et al. Increased expression of GluR2-flip in the hippocampus of the Wistar audiogenic rat strain after acute and kindled seizures. Hippocampus. 2010;20(1):125-133.

34. Guan Y, Guo W, Zou SP, Dubner R, Ren K. Inflammation-induced upregulation of AMPA receptor subunit expression in brain stem pain modulatory circuitry. Pain. 2003;104(1-2):401-413.

35. Kamphuis W, Monyer H, De Rijk TC, Lopes da Silva FH. Hippocampal kindling increases the expression of glutamate receptor-A flip and -B flip mRNA in dentate granule cells. Neurosci Lett. 1992;148(1-2):51-54.

36. Seifert G, Hüttmann K, Schramm J, Steinhäuser C. Enhanced relative expression of glutamate receptor 1 flip AMPA receptor subunits in hippocampal astrocytes of epilepsy patients with Ammon's horn sclerosis. J Neurosci. 2004;24(8):1996-2003.

37. Partin KM, Patneau DK, Mayer ML. Cyclothiazide differentially modulates desensitization of alpha-amino-3-hydroxy-5-methyl-4isoxazolepropionic acid receptor splice variants. Mol Pharmacol. 1994;46(1):129-138.

38. Quirk JC, Nisenbaum ES. Multiple molecular determinants for allosteric modulation of alternatively spliced AMPA receptors. $J$ Neurosci. 2003;23(34):10953-10962.

39. Sumioka A. Auxiliary subunits provide new insights into regulation of AMPA receptor trafficking. J Biochem. 2013;153(4):331-337.

40. Straub C, Tomita S. The regulation of glutamate receptor trafficking and function by TARPs and other transmembrane auxiliary subunits. Curr Opin Neurobiol. 2012;22(3):488-495.

41. Menuz K, Stroud RM, Nicoll RA, Hays FA. TARP auxiliary subunits switch AMPA receptor antagonists into partial agonists. Science. 2007;318(5851):815-817.

42. Huganir RL, Nicoll RA. AMPARs and synaptic plasticity: the last 25 years. Neuron. 2013;80(3):704-717.

43. Plant K, Pelkey KA, Bortolotto ZA, et al. Transient incorporation of native GluR2-lacking AMPA receptors during hippocampal long-term potentiation. Nat Neurosci. 2006;9(5):602-604.

44. Chen SR, Zhou HY, Byun HS, Pan HL. Nerve injury increases GluA2lacking AMPA receptor prevalence in spinal cords: functional significance and signaling mechanisms. J Pharmacol Exp Ther. 2013;347(3): $765-772$.

45. Hanley JG. Subunit-specific trafficking mechanisms regulating the synaptic expression of $\mathrm{Ca}(2+)$-permeable AMPA receptors. Semin Cell Dev Biol. 2014;27:14-22.

46. Rajasekaran K, Joshi S, Kozhemyakin M, et al. Receptor trafficking hypothesis revisited: plasticity of AMPA receptors during established status epilepticus. Epilepsia. 2013;54 Suppl 6:14-16.

47. Silverdale MA, Kobylecki C, Hallett PJ, et al. Synaptic recruitment of AMPA glutamate receptor subunits in levodopa-induced dyskinesia in the MPTP-lesioned nonhuman primate. Synapse. 2010;64(2): $177-180$.

48. Whitehead G, Jo J, Hogg EL, et al. Acute stress causes rapid synaptic insertion of Ca2+-permeable AMPA receptors to facilitate long-term potentiation in the hippocampus. Brain. 2013;136(Pt 12):3753-3765.

49. Costa LG, Giordano G, Faustman EM. Domoic acid as a developmental neurotoxin. Neurotoxicology. 2010;31(5):409-423.

50. Larm JA, Beart PM, Cheung NS. Neurotoxin domoic acid produces cytotoxicity via kainate- and AMPA-sensitive receptors in cultured cortical neurones. Neurochem Int. 1997;31(5):677-682.

51. Teitelbaum JS, Zatorre RJ, Carpenter S, et al. Neurologic sequelae of domoic acid intoxication due to the ingestion of contaminated mussels. N Engl J Med. 1990;322(25):1781-1787.

52. Lothman EW, Collins RC, Ferrendelli JA. Kainic acid-induced limbic seizures: electrophysiologic studies. Neurology. 1981;31(7):806-812.

53. Zhang J, Wang Y, Chi Z, et al. The AAA+ ATPase thorase regulates AMPA receptor-dependent synaptic plasticity and behavior. Cell. 2011;145(2):284-299.
54. Graebenitz S, Kedo O, Speckmann EJ, et al. Interictal-like network activity and receptor expression in the epileptic human lateral amygdala. Brain. 2011;134(Pt 10):2929-2947.

55. Hosford DA, Crain BJ, Cao Z, et al. Increased AMPA-sensitive quisqualate receptor binding and reduced NMDA receptor binding in epileptic human hippocampus. J Neurosci. 1991;11(2):428-434.

56. Ying Z, Babb TL, Comair YG, Bushey M, Touhalisky K. Increased densities of AMPA GluR1 subunit proteins and presynaptic mossy fiber sprouting in the fascia dentata of human hippocampal epilepsy. Brain Res. 1998;798(1-2):239-246.

57. Coombs ID, Soto D, Zonouzi M, et al. Cornichons modify channel properties of recombinant and glial AMPA receptors. $J$ Neurosci. 2012;32(29):9796-9804.

58. Swanson GT, Kamboj SK, Cull-Candy SG. Single-channel properties of recombinant AMPA receptors depend on RNA editing, splice variation, and subunit composition. $J$ Neurosci. 1997;17(1):58-69.

59. Grossman SD, Wolfe BB, Yasuda RP, Wrathall JR. Alterations in AMPA receptor subunit expression after experimental spinal cord contusion injury. J Neurosci. 1999;19(14):5711-5720.

60. Goa KL, Sorkin EM. Gabapentin. A review of its pharmacological properties and clinical potential in epilepsy. Drugs. 1993;46(3): 409-427.

61. Gower AJ, Noyer M, Verloes R, Gobert J, Wülfert E. ucb L059, a novel anti-convulsant drug: pharmacological profile in animals. Eur J Pharmacol. 1992;222(2-3):193-203.

62. White HS. Preclinical development of antiepileptic drugs: past, present, and future directions. Epilepsia. 2003;44 Supp1 7:2-8.

63. Durmuller N, Craggs M, Meldrum BS. The effect of the non-NMDA receptor antagonist GYKI 52466 and NBQX and the competitive NMDA receptor antagonist D-CPPene on the development of amygdala kindling and on amygdala-kindled seizures. Epilepsy Res. 1994;17(2): 167-174.

64. Namba T, Morimoto K, Sato K, Yamada N, Kuroda S. Antiepileptogenic and anticonvulsant effects of NBQX, a selective AMPA receptor antagonist, in the rat kindling model of epilepsy. Brain Res. 1994;638(1-2): $36-44$.

65. Barton ME, Peters SC, Shannon HE. Comparison of the effect of glutamate receptor modulators in the $6 \mathrm{~Hz}$ and maximal electroshock seizure models. Epilepsy Res. 2003;56(1):17-26.

66. Barton ME, Klein BD, Wolf HH, White HS. Pharmacological characterization of the $6 \mathrm{~Hz}$ psychomotor seizure model of partial epilepsy. Epilepsy Res. 2001;47(3):217-227.

67. Hanada T, Hashizume Y, Tokuhara N, et al. Perampanel: a novel, orally active, noncompetitive AMPA-receptor antagonist that reduces seizure activity in rodent models of epilepsy. Epilepsia. 2011;52(7): 1331-1340.

68. Milstein AD, Nicoll RA. Regulation of AMPA receptor gating and pharmacology by TARP auxiliary subunits. Trends Pharmacol Sci. 2008;29(7):333-339.

69. Barad Z, Shevtsova O, Arbuthnott GW, Leitch B. Selective loss of AMPA receptors at corticothalamic synapses in the epileptic stargazer mouse. Neuroscience. 2012;217:19-31.

70. Menuz K, Nicoll RA. Loss of inhibitory neuron AMPA receptors contributes to ataxia and epilepsy in stargazer mice. $J$ Neurosci. 2008;28(42):10599-10603.

71. Beyer B, Deleuze C, Letts VA, et al. Absence seizures in $\mathrm{C} 3 \mathrm{H} / \mathrm{HeJ}$ and knockout mice caused by mutation of the AMPA receptor subunit Gria4. Hum Mol Genet. 2008;17(12):1738-1749.

72. Russo E, Citraro R, De Fazio S, et al. Enhancement of anti-absence effects of ethosuximide by low doses of a noncompetitive alphaamino-3-hydroxy-5-methyl-4-isoxazolepropionic acid (AMPA) receptor antagonist in a genetic animal model of absence epilepsy. Epilepsy Behav. 2008;13(2):295-299.

73. Jakus R, Graf M, Ando RD, et al. Effect of two noncompetitive AMPA receptor antagonists GYKI 52466 and GYKI 53405 on vigilance, behavior and spike-wave discharges in a genetic rat model of absence epilepsy. Brain Res. 2004;1008(2):236-244. 
74. Micheletti G, Vergnes M, Marescaux C, et al. Antiepileptic drug evaluation in a new animal model: spontaneous petit mal epilepsy in the rat. Arzneimittelforschung. 1985;35(2):483-485.

75. Brophy GM, Bell R, Claassen J, et al. Guidelines for the evaluation and management of status epilepticus. Neurocrit Care. 2012;17(1):3-23.

76. Novy J, Logroscino G, Rossetti AO. Refractory status epilepticus: a prospective observational study. Epilepsia. 2010;51(2):251-256.

77. Hocker SE, Britton JW, Mandrekar JN, Wijdicks EF, Rabinstein AA. Predictors of outcome in refractory status epilepticus. JAMA Neurol. 2013;70(1):72-77.

78. Sutter R, Marsch S, Fuhr P, Rüegg S. Mortality and recovery from refractory status epilepticus in the intensive care unit: a 7-year observational study. Epilepsia. 2013;54(3):502-511.

79. Ferlisi M, Shorvon S. The outcome of therapies in refractory and super-refractory convulsive status epilepticus and recommendations for therapy. Brain. 2012;135(Pt 8):2314-2328.

80. Patneau DK, Vyklicky L Jr, Mayer ML. Hippocampal neurons exhibit cyclothiazide-sensitive rapidly desensitizing responses to kainate. J Neurosci. 1993;13(8):3496-3509.

81. Turski WA, Cavalheiro EA, Schwarz M, Czuczwar SJ, Kleinrok Z, Turski L. Limbic seizures produced by pilocarpine in rats: behavioural, electroencephalographic and neuropathological study. Behav Brain Res. 1983;9(3):315-335.

82. Walton NY, Treiman DM. Response of status epilepticus induced by lithium and pilocarpine to treatment with diazepam. Exp Neurol. 1988;101(2):267-275.

83. Goodkin HP, Joshi S, Mtchedlishvili Z, Brar J, Kapur J. Subunit-specific trafficking of GABA(A) receptors during status epilepticus. J Neurosci. 2008;28(10):2527-2538.

84. Rajasekaran K, Todorovic M, Kapur J. Calcium-permeable AMPA receptors are expressed in a rodent model of status epilepticus. Ann Neurol. 2012;72(1):91-102.

85. Fritsch B, Stott JJ, Joelle Donofrio J, Rogawski MA. Treatment of early and late kainic acid-induced status epilepticus with the noncompetitive AMPA receptor antagonist GYKI 52446. Epilepsia. 2010;51(1): $108-117$.

86. Langer M, Brandt C, Zellinger C, Löscher W. Therapeutic window of opportunity for the neuroprotective effect of valproate versus the competitive AMPA receptor antagonist NS1209 following status epilepticus in rats. Neuropharmacology. 2011;61(5-6):1033-1047.

87. Pitkänen A, Mathiesen C, Ronn LC, Møller A, Nissinen J. Effect of novel AMPA antagonist, NS1209, on status epilepticus. An experimental study in rat. Epilepsy Res. 2007;74(1):45-54.

88. Figueiredo TH, Qashu F, Apland JP, Aroniadou-Anderjaska V, Souza AP, Braga MF. The GluK1 (GluR5) Kainate/\{alpha\}-amino-3-hydroxy5-methyl-4-isoxazolepropionic acid receptor antagonist LY293558 reduces soman-induced seizures and neuropathology. J Pharmacol Exp Ther. 2011;336(2):303-312.

89. Hitiris N, Mohanraj R, Norrie J, Sills GJ, Brodie MJ. Predictors of pharmacoresistant epilepsy. Epilepsy Res. 2007;75(2-3):192-196.

90. Pitkänen A, Nehlig A, Brooks-Kayal AR, et al. Issues related to development of antiepileptogenic therapies. Epilepsia. 2013;54 Suppl 4: $35-43$.

91. Schmidt D. Is antiepileptogenesis a realistic goal in clinical trials? Concerns and new horizons. Epileptic Disord. 2012;14(2):105-113.

92. Sun H, Kosaras B, Klein PM, Jensen FE. Mammalian target of rapamycin complex 1 activation negatively regulates polo-like kinase 2-mediated homeostatic compensation following neonatal seizures. Proc Natl Acad Sci U S A. 2013;110(13):5199-5204.

93. Li SY, Xu DS, Jia HT. AGS-induced expression of Narp is concomitant with expression of AMPA receptor subunits GluR1 and GluR2 in hippocampus but not inferior colliculus of P77PMC rats. Neurobiol Dis. 2003;14(3):328-335.

94. Sommer C, Roth SU, Kiessling M. Kainate-induced epilepsy alters protein expression of AMPA receptor subunits GluR1, GluR2 and AMPA receptor binding protein in the rat hippocampus. Acta Neuropathol. 2001;101(5):460-468.
95. Prince HC, Tzingounis AV, Levey AI, Conn PJ. Functional downregulation of GluR2 in piriform cortex of kindled animals. Synapse. 2000;38(4):489-498.

96. Sanchez RM, Koh S, Rio C, et al. Decreased glutamate receptor 2 expression and enhanced epileptogenesis in immature rat hippocampus after perinatal hypoxia-induced seizures. J Neurosci. 2001;21(20): 8154-8163

97. Talos DM, Sun H, Zhou X, et al. The interaction between early life epilepsy and autistic-like behavioral consequences: a role for the mammalian target of rapamycin (mTOR) pathway. PLoS One. 2012;7(5):e35885.

98. van der Kooij MA, Ohl F, Arndt SS, Kavelaars A, van Bel F, Heijnen CJ. Mild neonatal hypoxia-ischemia induces long-term motor- and cognitive impairments in mice. Brain Behav Immun. 2010;24(5):850-856.

99. Talos DM, Follett PL, Folkerth RD, et al. Developmental regulation of alpha-amino-3-hydroxy-5-methyl-4-isoxazole-propionic acid receptor subunit expression in forebrain and relationship to regional susceptibility to hypoxic/ischemic injury. II. Human cerebral white matter and cortex. J Comp Neurol. 2006;497(1):61-77.

100. Talos DM, Fishman RE, Park H, et al. Developmental regulation of alpha-amino-3-hydroxy-5-methyl-4-isoxazole-propionic acid receptor subunit expression in forebrain and relationship to regional susceptibility to hypoxic/ischemic injury. I. Rodent cerebral white matter and cortex. J Comp Neurol. 2006;497(1):42-60.

101. Rakhade SN, Fitzgerald EF, Klein PM, et al. Glutamate receptor 1 phosphorylation at serine 831 and 845 modulates seizure susceptibility and hippocampal hyperexcitability after early life seizures. J Neurosci. 2012;32(49):17800-17812.

102. Aujla PK, Fetell MR, Jensen FE. Talampanel suppresses the acute and chronic effects of seizures in a rodent neonatal seizure model. Epilepsia. 2009;50(4):694-701.

103. Jensen FE, Blume H, Alvarado S, Firkusny I, Geary C. NBQX blocks acute and late epileptogenic effects of perinatal hypoxia. Epilepsia. 1995;36(10):966-972.

104. Lippman-Bell JJ, Rakhade SN, Klein PM, et al. AMPA receptor antagonist NBQX attenuates later-life epileptic seizures and autistic-like social deficits following neonatal seizures. Epilepsia. 2013;54(11):1922-1932.

105. Hoeffer CA, Klann E. mTOR signaling: at the crossroads of plasticity, memory and disease. Trends Neurosci. 2010;33(2):67-75.

106. Guo D, Zeng L, Brody DL, Wong M. Rapamycin attenuates the development of posttraumatic epilepsy in a mouse model of traumatic brain injury. PLoS One. 2013;8(5):e64078.

107. Russo E, Citraro R, Donato G, et al. mTOR inhibition modulates epileptogenesis, seizures and depressive behavior in a genetic rat model of absence epilepsy. Neuropharmacology. 2013;69:25-36.

108. Ryther RC, Wong M. Mammalian target of rapamycin (mTOR) inhibition: potential for antiseizure, antiepileptogenic, and epileptostatic therapy. Curr Neurol Neurosci Rep. 2012;12(4):410-418.

109. Grant KA, Colombo G, Grant J, Rogawski MA. Dizocilpine-like discriminative stimulus effects of low-affinity uncompetitive NMDA antagonists. Neuropharmacology. 1996;35(12):1709-1719.

110. Muller WE, Mutschler E, Riederer P. Noncompetitive NMDA receptor antagonists with fast open-channel blocking kinetics and strong voltage-dependency as potential therapeutic agents for Alzheimer's dementia. Pharmacopsychiatry. 1995;28(4):113-124.

111. Kornhuber J, Weller M. Amantadine and the glutamate hypothesis of schizophrenia. Experiences in the treatment of neuroleptic malignant syndrome. J Neural Transm Gen Sect. 1993;92(1):57-65.

112. Löscher W, Hönack D. Anticonvulsant and behavioral effects of two novel competitive N-methyl-D-aspartic acid receptor antagonists, CGP 37849 and CGP 39551, in the kindling model of epilepsy. Comparison with MK-801 and carbamazepine. J Pharmacol Exp Ther. 1991;256(2):432-440.

113. Yamaguchi S, Donevan SD, Rogawski MA. Anticonvulsant activity of AMPA/kainate antagonists: comparison of GYKI 52466 and NBOX in maximal electroshock and chemoconvulsant seizure models. Epilepsy Res. 1993;15(3):179-184. 
114. Walters MR, Kaste M, Lees KR, et al. The AMPA antagonist ZK 200775 in patients with acute ischaemic stroke: a double-blind, multicentre, placebo-controlled safety and tolerability study. Cerebrovasc Dis. 2005;20(5):304-309.

115. Hibi S, Ueno K, Nagato S, et al. Discovery of 2-(2-oxo-1phenyl-5-pyridin-2-yl-1,2-dihydropyridin-3-yl)benzonitrile (perampanel): a novel, noncompetitive $\alpha$-amino-3-hydroxy-5-methyl4-isoxazolepropanoic acid (AMPA) receptor antagonist. J Med Chem. 2012;55(23):10584-10600.

116. Tarnawa I, Farkas S, Berzsenyi P, Pataki A, Andrási F. Electrophysiological studies with a 2,3-benzodiazepine muscle relaxant: GYKI 52466. Eur J Pharmacol. 1989;167(2):193-199.

117. Tarnawa I, Farkas S, Berzsenyi P, Pátfalusi M, Andrási F. Reflex inhibitory action of a non-NMDA type excitatory amino acid antagonist, GYKI 52466. Acta Physiol Hung. 1990;75 Suppl:277-278.

118. Weiser T. AMPA receptor antagonists for the treatment of stroke. Curr Drug Targets CNS Neurol Disord. 2005;4(2):153-159.

119. Faught E. BGG492 (selurampanel), an AMPA/kainate receptor antagonist drug for epilepsy. Expert Opin Investig Drugs. 2014;23(1): 107-113.

120. Gomez-Mancilla B, Brand R, Jürgens TP, et al. Randomized, multicenter trial to assess the efficacy, safety and tolerability of a single dose of a novel AMPA receptor antagonist BGG492 for the treatment of acute migraine attacks. Cephalalgia. 2014;34(2):103-113.

121. Chappell AS, Sander JW, Brodie MJ, et al. A crossover, add-on trial of talampanel in patients with refractory partial seizures. Neurology. 2002;58(11):1680-1682.

122. Pascuzzi RM, Shefner J, Chappell AS, et al. A phase II trial of talampanel in subjects with amyotrophic lateral sclerosis. Amytroph Lateral Scler. 2010;11(3):266-271.

123. Grossman SA, Ye X, Chamberlain M, et al. Talampanel with standard radiation and temozolomide in patients with newly diagnosed glioblastoma: a multicenter phase II trial. J Clin Oncol. 2009;27(25): 4155-4161.

124. Langan YM, Lucas R, Jewell H, et al. Talampanel, a new antiepileptic drug: single- and multiple-dose pharmacokinetics and initial 1-week experience in patients with chronic intractable epilepsy. Epilepsia. 2003;44(1):46-53.

125. Luszczki JJ. Third-generation antiepileptic drugs: mechanisms of action, pharmacokinetics and interactions. Pharmacol Rep. 2009; 61(2):197-216.

126. European Medicines Agency. Fycompa [summary of product characteristics]. Available from: http://www.ema.europa.eu/docs/en_ GB/document_library/EPAR_-_Product_Information/human/002434/ WC500130815.pdf. Accessed February 28, 2014.
127. Templeton D. Pharmacokinetics of perampanel, a highly selective AMPA-type glutamate receptor antagonist. Epilepsia. 2009; 50 Suppl 11:98.

128. Hanada T. The discovery and development of perampanel for the treatment of epilepsy. Expert Opin Drug Discov. 2014;9(4): 449-458.

129. French JA, Krauss GL, Biton V, et al. Adjunctive perampanel for refractory partial-onset seizures: randomized phase III study 304 . Neurology. 2012;79(6):589-596.

130. French JA, Krauss GL, Steinhoff BJ, et al. Evaluation of adjunctive perampanel in patients with refractory partial-onset seizures: results of randomized global phase III study 305. Epilepsia. 2013;54(1): 117-125.

131. Krauss GL, Serratosa JM, Villanueva V, et al. Randomized phase III study 306: adjunctive perampanel for refractory partial-onset seizures. Neurology. 2012;78(18):1408-1415.

132. Gidal BE, Ferry J, Majid O, Hussein Z. Concentration-effect relationships with perampanel in patients with pharmacoresistant partial-onset seizures. Epilepsia. 2013;54(8):1490-1497.

133. Kerling F, Kasper BS. Efficacy of perampanel: a review of clinical trial data. Acta Neurol Scand Suppl. 2013;(s197):25-29.

134. Serratosa JM, Villanueva V, Kerling F, Kasper BS. Safety and tolerability of perampanel: a review of clinical trial data. Acta Neurol Scand. 2013;127 Suppl s197:30-35.

135. Steinhoff BJ, Laurenza A, Yang H, Satlin A. Safety profile of perampanel as an adjunctive treatment for partial-onset seizures. J Symptoms Signs. 2014;3(2):64-70.

136. Steinhoff BJ. Efficacy of perampanel: a review of pooled data. Epilepsia. 2014;55 Supp1 1:9-12.

137. US Food and Drug Administration. Fycompa [prescribing information]. 2012. Available from: http://www.accessdata.fda.gov/ drugsatfda_docs/label/2012/202834lbl.pdf. Accessed February 28, 2014.

138. Bagal SK, Brown AD, Cox PJ, et al. Ion channels as therapeutic targets: a drug discovery perspective. J Med Chem. 2013;56(3):593-624.

139. Dooley DJ, Taylor CP, Donevan S, Feltner D. Ca2+ channel $\alpha 2 \delta$ ligands: novel modulators of neurotransmission. Trends Pharmacol Sci. 2007;28(2):75-82.

140. Vink S, Alewood PF. Targeting voltage-gated calcium channels: developments in peptide and small-molecule inhibitors for the treatment of neuropathic pain. Br J Pharmacol. 2012;167(5): 970-989.

141. Parsons CG, Gilling K. Memantine as an example of a fast, voltagedependent, open channel N-methyl-D-aspartate receptor blocker. Methods Mol Biol. 2007;403:15-36.
Journal of Receptor, Ligand and Channel Research

\section{Publish your work in this journal}

The Journal of Receptor, Ligand and Channel Research is an international, peer reviewed, open access, online journal. The journal welcomes laboratory and clinical findings in the fields of biological receptors, ligands, channel and signal transduction research including: receptors and signaling; ligands; transporters, pores and channels; binding and activation; receptor

\section{Dovepress}

regulation; role of receptors in diseases and their treatment; molecular basis of membrane structure and functions; molecular models of membranes. The manuscript management system is completely online and includes a very quick and fair peer-review system. Visit http://www.dovepress.com/ testimonials.php to read real quotes from published authors. 